\title{
Language or Protolanguage
}

\author{
Aftab Yashar Hajizade ${ }^{1}$ \\ ${ }^{1}$ Azerbaijan University of Languages, Azerbaijan \\ Correspondence: Aftab YAshar Hajizade, Azerbaijan University of Languages, Azerbaijan. E-mail: \\ aftabyashar@yahoo.com
}

Received: January 12, 2016 Accepted: February 2, 2016 Online Published: March 28, 2016

doi:10.5539/ijel.v6n2p145

URL: http://dx.doi.org/10.5539/ijel.v6n2p145

\begin{abstract}
The article investigates the communication system of living beings, especially the non-humans. The author tries to analyse that if there are any relations between the evolution of the language and the communication system of the species. The author studies the Animal Communication System by Mark Hauser.

According to the investigations mostly all living beings communicate to each other with any way. Humans, animals, birds, insects and even bacteria are able to communicate with each other. This reason caused Mark Hauser to investigate Animal Communication System (ACS) decades ago. Basing on his observations in different environments and with different kinds of animals for many years he defined that ACS covers three broad categories.

He named those categories as signals and gave such a division:

1) The signals that relate to individual survival;

2) The signals that relate to mating and reproduction;

3) The signals that relate to other kinds of interactions among members of the same species; they are called social signals $(2, \mathrm{~s} .16)$.

The author investigates each of these categories by giving detailed examples from different sources. The author comes to the conclusion that the non-humans do not concepts as some people think. They only have abilities that were given to them by birth. And they perform their abilities in each situation.
\end{abstract}

Keywords: human, non-human, species, communicate, animal, system, concept, ability, pidgin, niche, construction

\section{Introduction}

The three broad categories of ACS have been investigated separately for many years. It is necessary not to think that one signal should be observed only in a single category.

Some signals may not only be observed in a single category. For example: one may find a signal of appeasement as a social signal when the enemy looks to be winning you, but on the other hand it can also fall under survival because if you don't make it you can be killed. It is important to stress that no signals are proved to fall outside of those three areas. So, all means that animals communicate with each other such as all the flashes, calls, gestures, and others are realized according to these signals. For example, let us look through such a situation related to survival. Every animal tries to survive in a difficult situation, and it tries to escape from the situation by running or by calling attention of its close relatives who carry many of the same genes for help. According to the situation the animal may stay alive or may be killed. The purpose of this situation is that by making the call for help the animal is able to attract its close relatives. It means that the animals who carry the same genes are aware of the danger. The biologists call it "inclusive fitness" (s.16-17).

\section{Scope of the Study}

Let us analyse the above mentioned signals giving explanations to each of them. Sometimes it is possible to hear such thoughts that the warning calls are fully automatic. We can compare it like the way we blink if someone pokes a finger in front of our eyes. Poor animal sees the leopard and cries; simply it cannot stand still. Generally, the scientists prove that the animals cannot speak, but it doesn't mean that it is dumb or unable to speak. They don't speak when they are alone like humans, or as the human can speak when he is alone by 
himself, the animals can also mutter when they are by themselves. They speak, or communicate carefully when they are among the enemies, but when they are among the relatives they can behave independently like humans. The situation explains the survival signal. Other situation: if the animal announce the discovery of food the same standard of inclusive fitness applies. It means benefit your brother and and you are giving your own genes. So we can say that all survival calls relate directly to increasing fitness.

The second kind of signal is the reproduction one. By using this signal the animal may announce: "I am a male/female of species X." The signals that they give simply ensure that the right sexes of the right species get together at the right times.

Using social signals animals can relate to any kind of interaction between members of the same species. For example, infant apes poke their mother for getting her to feed them. This method can be named as "nursing poke".

In the result of ACS the scientists discovered two main features - they grew from behaviours not originally meant for communication; they respond only to situations that directly affect fitness. In this case we have to face the enourmous size of the problem that language poses for the biological sciences. The humans think that the uniqueness of the language is the core of the problem. But most of the scientists do not agree with it. Most things are unique in humans such as bipedalism and absense of the body hair. Some other kinds of species have uniqueness too. For example, the trunks of elephants, the necks of the giraffes, the tail of peacocks, etc. But no other living being has a language. Let us turn to the just mentioned features again. For example, not having bipedalism is not a special factor. Birds manage it; kangaroos come close. The other feature, hairlessness can not be considered as uniqueness. We can notice it in some mammals. The young of many mammalian species emerge naked from the womb and only later grow hair. The psycholinguist Steven Pinker gives an interesting explanation while explaining the features that are not human but is genuinely unique; it is the elephant's trunk. In his book The Language Instict he writes about this issue and analyses it. He uses the elephant's trunk to make language seem less of an anomaly than it really is. He claims that unique stuff can evolve through natural selection. He writes: "a language instinct unique to modern humans poses no more of a paradox than a trunk unique to elephants." (p. 21)

Some other scientists such as Derek Bickerton do not agree with him. He thinks that Pinker is not right. He explains that an elephant's trunk results from hyperdevelopment of the nose. Of course, anatomists can point to the exact physical ingredients that went into its makeup. But Pinker doesn't tell us what ingredients went into the making of the language. That is why we can say that uniqueness is not issue (2, s.21).

Investigations prove that the linguists, bilogists, anatomists, etc. who are studying the evolution of the language can not really tackle or explain the issue. It is necessary to point out that the means of ACS such as calls, flashes, gestures and others are meaningless if they are used outside these situations. They carry meanings only if they are used in the situations. The units of the language such as words, manual signs are not. They have meanings in each situation. For example, I am at home with my friend and suddenly if I cry that "Hey, look, the tiger is going to attack on you". Certainly, my friend will understand that I am joking. But anyway the meaning of the sentence can make my friend catch the real meaning of the situation. He knows that what may happen if the tiger is about to attack him in reality. Derek Bickerton states that while investigating the evolution of the language the experiments of pidgins and creols helped him much. A pidgin is what people produce when they have to talk to other people but don't have a common language. For example, if you are in a strange place, you try to communicate to the people around you, and they also try to communicate with you. In this case you can use pidgins. We should like to stress that some scientists do not support Bickerton's ideas on this issue. For example, the psycholinguist Dan Slobin at the University of Californiya, Berkeley, does not think that he is right. Slobin insists that the people who do not understand each other use pidgin only in that case that they already have at least one full human language. Otherwise they cannot communicate even using pidgins. Bickerton doesn't agree with Slobin. He insists on his own idea. He claims that the language is the language; you may use any protolanguage for to communicate with each other. Natuarally protolanguage is not true language, but it has made up of languagelike elements $(2,40)$.

For understanding the protolanguage a lot of experiments have been carried out on smaller animals, or species investigating the differences between homology and analogy. Homology is when the same feature occurs in two species. The two sepecies share the same feature because they have their common ancestor. Before evo-devo, people thought that homology might be found only in among closely related species. They didn't think to choose the wings of birds and bats as examples of homology. We need to go back 300 million years ago for to find the common ancestor of birds and bats. There we might find many species that didn't have wings. So, 
wings are just considered to be analogies. They are the result of aerodynamic factors. The evolutionary biology of twentieth-century Ernst Mayr wrote in 1963: "Much has been learned about gene physiology makes it evident that the search for homologous genes is quite futile except in very close relatives. If there is only one efficient solution for a certain functional demand, very different gene complexes will come up with the same solution, no matter how different the pathway by which it is achieved. The saying 'Many roads lead to Rome' is as true in evolution as in daily affairs" (p. 129).

As we stated above many birds and bats have the same genes as their ancestors. This case is called "deep homology". For studying the homology of any species it is necessary to study its deep homology first of all. This is the same in flies and mice. Genes may be observed in various combinations and in different kinds of environments.

Giraffes necks are much longer than ours, but they have the same number of bones just seven like us. Genes that govern bone length makes bone longer or shorter, but they cannot change the number of bones because it is not their job. We should like to stress again that it is not the job of genes to form the number of bones. It is undeniable that there are some strange mutation during this investigation.

As we see the direction leads us to the beliefs, or theories of N.Chomski's about the evolution of the language. It becomes clear that deep homology doesn't form the behaviour. It helps to form the parts of speech, there is not any question to this and Bickerton also thinks that particular behaviour is not the result of deep homology. But language is the form of behaviour - behaviour is strengthened by the help of genes. Genes help to form the parts of the body (naturally the parts of the brain have also been included here) and the parts of the body help to form the behaviour. But we should again like to state that there are a lot of independent genes which often change, and they help us to look for the origin of the genes. So if scientists want to look for the origin of something first of all they need to look for the behaviour not the genes. The theory of Niche construction also explains it. Niche construction is the process in which an organism alters its own environment, often but not always in a manner that increases its chances of survival. Changes that organisms bring about in their worlds that are of no evolutionary or ecological consequence are not examples of niche construction. The behaviors are increasing because the construction of niches demand them and the process is impossible without them (2, s.20-21).

As we stated above ACS have always been interested humans. This process was discovered by Karl von Frisch's studies of honeybee communication half a century ago. He managed to study the stange abilities of honeybees in the result of his observations. For example, how the honey bees measure the distance, etc. Bees are capable of displacement. Bees are too far from the humans. Behaviour is seen as a monopoly of the genes, there cannot possibly be a connection. Everything began to change since the niche construction has appeared. So, let's look at the bees and how they behave and why.

Bees are the most hardworking and the cleverest species in the world. Bees are considered to be eurosocial. There is only one female, the queen, and there are a lot of males in every community of bees. It means that the other members of the community are sterile and are the siblings of one another. We should like to mention that the coorporation and cohesion is much stronger among the bees than other species. If something is good for one, it is good for the other one too. If bees can not store enough honey, it means that all of them will die next winter. We cannot observe such a character among other species. For bees the sources of food are rose fields. These sources of food may last one or two days. If a single bee finds such a source, it doesn't expolit it fully. For the good of inself and all, it must recruit its nestmates to help it. The members of one honeycomb do not let the members of other honeycomb enter their honeycomb. Each bee inside the honeycomb has its duty for to fulfil. Each of the honeycombs has its guards. There are some groups inside the honeycombs whose duty are to help the other members. For example, if one bee brings some juice, or water, etc. those groups help the bee to place its bringings, etc. Water has a great role in bees' giving birth. In winter months bees stay in their nests. If the temperature is below 15 degrees, bees do not want to leave their nests. The important point is that there cannot be an unemployed bee among bees. All work of bees' family has been organized basing on rules. The work has been divided into some parts. There are guardians, scouts, fighters, the bees that inform weather forecast, bees that give milk, male and female bees, the bees that collect the honey exactly and at last mother bee in the family of bees. Mother bee lays egg that is much more than its weigh. The bees which give milk put bee milk on the eggs and cover them with wax. If this process may last for three days, it means that after 21 days the worker bees are born. It this process may last for 16 days, then the mother bee is born. The newly-born infant bee rests for 3 days then it works till the end of its life. The life of a worker bee is 30-40 days. If a bee brings juice into the nest, a guard meets it. If the trunk and the legs of the bee are not full, then it is sent back. As we stated above bees always recruit their nestmates to help each other. Recruitment - it is the point that we have been trying to come since we began to talk about bees. Recruitment is the term that turns out to be the key word in the birth of 
language. The sites for which bees must recruit nestmates may lie several kilometer from the hive. Several minutes must pass between the bee finds the source and when it passes on the information. For recruiting effectively bees need to tell other bees where food sources are found and how far the sources are. They give this information by dancing. This kind of dance belonging to bees is called "round dance" as they dance in circles. If the distance is farther, they dance in a series of elliptical loops, waggling their bodies as they come through the straightaway in the middle, o that is called the "waggle dance." If they dance faster, it means that the site is farther. So bees execute an amasing transformation based on the current position of the sun. They compute the angle between the sun's current position. If we try to draw such an angle, we are sure not to draw it. Not a human is able to compute such an angle that bees execute. Bees are the only species that do all it all in their heads. In this case we remember the size of our brains and the bees'. They have a pinhead-sized brain compared to ours. Then we will think that they use their instincts. Yes, bees are clear proof for the model of communication system. But it is important to mention that they are not the best model.

The people who believe in behavioral sciences often claim that "but of courseanimals have concepts like ours!" (p. 197). To deny this means that there is discontinuity between humans and nonhumans. It also means that there is one possible discontinuty between language and all other forms of communication. With these the building of Darwinian bigan to shake gradually. Or it seems like this. Are we ready to accept that bacteria also have concepts? The question that whether or not animals have concepts like ours is an empirical one. Let us again give examples that were carried out on animals. Richard Hernstein, the psychologist, carried out a series of experiments with pigeons back in the seventies. The scientists are also interested in those experiments nowadays. We should like to mention that Hernstein himself was also excited about the results of the experiments with pigeons. He wrote: "How can animals with such powers of classification still seem stupid in some ways?" Maybe their brains work differently than humans.

First of all Hernstein trained pigeons to distinguish between pictures that ahd trees in them and pictures that didn't have. If the pigeons saw a tree in the picture, they pecked it, and if there was not any tree they didn't peck it. This experiment may look easy, but don't forget that we are speaking about the pigeons. As the pigeons spend of their lives on the trees it is not difficult for them to distinguish the trees. So Hernstein replaced trees with the pictures of people. But pigeons also found the pictures of the people easily. Pigeons have usually seen people. But have the pigeons seen the fish? So Hernstein trained his pigeons to distinguish the fish pictures. But again the pigeons did equally well. Of course, the pigeons have never seen fish before. But that didn't stop them from recognizing almost every fish they saw. How did they do it? Does it mean that they have concepts too? Of course not. Most scientists as well as Bickerton thinks that it doesn't mean that pigeons have some concepts in their brains. Pigeons just have a good memory. That is all. Now let us go to the wild nature. Some experiments have alo been carried out on scrub jays. Scrub jays are usually found in the West. They live by collecting seeds. They hide the seeds and when winter comes they already have food supply. During the whole season they may hide thousands of seeds in different places. It is interesting that when they fly back they remember them all. They even remember the places of perishable seeds and less perishable ones too $(4, \mathrm{~s} .29)$. The scientists claimed that most of the humans could remember the places of any things that were hidden somewhere many months ago. But it doesn't mean that animals, insects and other non-humans have minds, or concepts too. Their abilities that we have mentioned don't mean that their mental capacity can develop.

\section{Conclusion}

Basing on the experiments that the scientists carried out on different kinds of species the scientists think that the evolution doesn't develop as we observe it. The non-humans such as animals, birds, insects and others do the things that were given them by birth. They do what they have to do. Natural selection leads the humans and the non-humans to their own ways. The capacity of each of the species has been given to them by God. It doesn't mean that they have intelligence like humans. Many experimens have been carried out on many species and the common conclusion is that no more concepts than three have ever been observed in the animals, or non-humans. There are measures that go farther than congitiveness. The humans have gaind their language in this way of development. The other species do the capacity that was given to them by birth. The humans need to develop their language for reaching the right place. The other species never wanted such a need, or didn't need it. They have always lived with the abilities that were given to them, and we think that they are happy with this.

\section{References}

Bickerton, D. (1981). Roots of Language. Ann Arbor, Mich., Karoma.

Bickerton, D. (1995). Language and human Behaviour. Seattle: University of Washington Press.

Bickerton, D. (2010). Adam's tongue. United States of America. 
Chomsky, N. (1957). Syntactic Structures. The Hague: Mouton.

Chomsky, N. (1959). A review of B. F. Skinner's Verbal Behaviour. Language.

Chomsky, N. (1965). Aspects of the theory of syntax. Cambridge, Mass.: MIT Press.

Chomsky, N. (1972). Language and mind (Enlarged edition). New York: Harcourt Brace Jovanovich.

Ernst, M. (1963). Animal species and evolution. Cambridge, Mass.: Harward University Press.

Hauser, M. D. (1996). The evolution of communication. Cambridge, Mass.: MIT Press.

Hernstein, R. J. (1979). Acquisition, generalization, and discrimination reversal of a natural concept. Journal of Experimental Psychology: Animal Behaviour Process, 5(2), 116-129.

Veyselli, F. Y. (2007). Language. Baku: Education NPM.

\section{Copyrights}

Copyright for this article is retained by the author(s), with first publication rights granted to the journal.

This is an open-access article distributed under the terms and conditions of the Creative Commons Attribution license (http://creativecommons.org/licenses/by/3.0/). 